\title{
МЕДІАДОСЛІДЖЕННЯ
}

\author{
Visn. Lviv. Univ., Ser. Zhurn. 2020: 48; 224-236 • DOI: http://dx.doi.org/10.30970/vjo.2020.48.10563
}

УДК 070(82):32(477)

\section{УКРАЇНСЬКЕ ПИТАННЯ У ДЗЕРКАЛІ АРГЕНТИНСЬКОЇ ПРЕСИ (НА ПРИКЛАДІ CLARÍN, LA NACIÓN TA INFOBAE)}

\author{
Юрій Мельник \\ Львівський національний університет імені Івана Франка \\ вул. Генерала Чупринки, 49, 79044, Львів, Україна \\ e-mail:melnykiurii@gmail.com \\ https://orcid.org/0000-0002-2825-9925
}

У статті окреслено протистояння проукраїнського та проросійського бачення подій в Україні у 2014-2019 рр. у дзеркалі трьох ключових видань Аргентини. Дослідження показало, що діапазон оцінок доволі широкий, від явно проукраїнської до явно проросійської. Поширеним явищем є занепокоєння щодо наслідків цих подій для світу та Аргентини - без чітких намірів розібратися у їхніх причинах.

Ключові слова: аргентинські медіа, Clarín, La Nación, Infobae, образ України, українське питання.

Постановка проблеми. Спровоковане українською проблемою загострення взаємин між Росією та Сполученими штатами (і Заходом в цілому) вивело інформаційну війну на новий рівень інтенсивності, який дався взнаки в усіх регіонах планети, в тому числі в Латинській Америці. Ця частина світу віддавна є полем протистояння (передусім - інформаційного) між Сполученими Штатами, традиційним домініоном у регіоні, уряд яких ще з часів президента Джеймса Монро вважає Новий Світ своєю сферою впливу, та альтернативними глобальними гравцями (Росією й Китаєм).

У деяких країнах Латинської Америки суттєво сильніші інформаційні позиції США, у деяких безапеляційно домінує проросійська точка зору, в тому числі на події в Україні. Є група проміжних, нейтральних країн, візія постмайданної України у яких неоднозначна. Серед таких країн - Аргентина, офіційна позиція якої щодо протистояння впродовж останніх п’яти років була неоднозначною: у 2014-2015 рр. президентом країни була Крістіна Фернандес де Кіршнер, яка часто демонструвала симпатії до Росії. Ї̈̈ на посаді глави держави замінив Маурісіо Макрі, якому приписують провашингтонський порядок денний. У жовтні 2014 р. Кіршнер вітала входження іспаномовної версії Russia Today в інформаційний простір Аргентини, що, поряд із негативними тенденціями в інших країнах регіону, спонукало авторів $\mathrm{New}$ York Times задуматися над «деградацією незалежної журналістики» та «насліду-

(C) Мельник Ю., 2020 
ванням підходу містера Путіна до свободи медіа» на континенті․․ За президентства Макрі, у червні 2016 р., російський телеканал виключили з безкоштовної державної телемережі, через що непокоїлися вже російські медіа. Щоправда, за півтора року, в рамках міждержавних договорів найвищого рівня, Russia Today повернув собі привілейоване місце в системі аргентинського телебачення, про що схвально відгукнувся президент Путін.

Приклад із позиціями Russia Today в Аргентині відображає рівень конкурентності та гостроти боротьби за інформаційний простір цієї країни та відсутність явного домінанта у ній. Аргентина - країна Великої двадцятки, один із ключових гравців у регіоні. Перемога прихильного до України трактування подій у Криму і на Донбасі саме у таких країнах означатиме суттєвий крок у напрямку до перемоги над Росією у глобальній інформаційній війні загалом. Саме тому таким важливим є дослідження цієї проблематики.

Мета статті - окреслити візію подій в Україні у 2014-2019 рр. трьох ключових видань Аргентини.

Джерельна база дослідження - публікації двох провідних щоденних газет країни, Clarín та La Nación, а також впливового новинного сайту Infobae. За даними All$Y_{\text {YuCanRead }}^{2}$ та SimilarWeb ${ }^{3}$, це три найпопулярніші джерела інформації в Аргентині.

Хронологічні рамки дослідження - період збройного протистояння в Україні (2014-2019 рр.).

Методологічна основа дослідження. Використані для дослідження журналістські тексти були знайдені на офіційних сайтах відповідних видань за ключовим словом «Україна» («Ucrania»). Матеріали із нерелевантними згадками України були відсіяні, усі інші були проаналізовані із застосуванням індукції, порівняння, класифікаційного аналізу, контент-аналізу, аналізу лексики.

Виклад основного матеріалу дослідження. La Nación. У більшості аналітичних та публіцистичних матеріалів, опублікованих у La Nación, відображена проукраїнська точка зору. Доволі типовою для газети є стаття під назвою «Путін і мета дестабілізувати Україну» (лютий 2015 р.): «Бої між силами центрального уряду цієї країни та сепаратистськими ополченцями, яких продовжує масово, хоч і таємно, підтримувати Російська Федерація... Владімір Путін знову спрямував на Донбас усі види зброї, включно зі зброєю важкого калібру та підвищеної небезпеки, а також допоміжну військову техніку... Він робив це непрямо, приховуючи свої кроки і уникаючи, щоб його військові, які розгорнули широку діяльність навколо Донецька та Луганська, показували свою справжню форму або могли бути легко ідентифіковані, як того вимагають норми міжнародного права у разі збройних конфліктів... Путін прагне тримати Україну зануреною в атмосферу постійної війни, аби завадити їй

1 Bosoer, F., Filchenstein, F. (2014), «Russia Today, Argentina Tomorrow», New York Times, October 21, available at: $\underline{t . l y / m g V 9 A}$ (accessed 6 November 2019).

2 All you can read (2019), «Top 30 Argentina Newspapers \& News Media», available at: t.ly/jRVZv (accessed 6 November 2019).

3 SimilarWeb (2019), «Top sites ranking for News And Media in Argentin», disponible en: t.ly/ngVZY (accessed 6 November 2019). 
вільно поглиблювати зв’язки зі Старою Європою та віддалятися від Москви. У цьому Путін був абсолютно безкомпромісний» ${ }^{4}$.

Публіцист Еміліо Карденас [Emilio Cárdenas] і у вересні 2014 р., і у липні 2019 р. однаково будує свої тексти на критиці керівництва Росії за агресивну зовнішню політику, порушення світового порядку, гібридну війну стосовно України, замах на Скрипалів у Солсбері: «Цілком зрозуміло, що російські війська не тільки безпосередньо вторглися на українську територію, але, окрім того, Росія постачала - i продовжує постачати - всі види озброєння та спорядження для тих, хто з сепаратистськими чи загарбницькими ідеалами воює проти уряду України»; З За словами Еміліо Карденаса, в інтерв'ю Financial Times Путін розмірковує про загрози миру та безпеки у світі, «не згадуючи ні про сумнівну насильну анексію Криму (так, ніби це «доконаний факт»); ні про очевидну підтримку, яку Росія надала сепаратистам Східної України» ${ }^{6}$ Більшість матеріалів, у яких йдеться про Україну, насправді присвячені російському президенту, щодо якого газета налаштована критично: «Владімір Путін ще раз підтвердив, що він небезпечний лідер з огляду на зневагу та порушення норм міжнародного права, а також на постійну агресію, об'єктом якої він зробив Україну, чиїй територіальній цілісності загрожує Російська Федерація»7.

Водночас, Луїс Бассетс [Luis Bassets] у березні 2014 р. намагається окреслити своїм читачам кремлівське бачення подій у Криму: «Росія розглядає наслідки холодної війни подібно до того, як веймарська Німеччина бачила мир у Версалі, включаючи ідею удару ножем у спину»", а у червні того ж року пропонує Україні “фінляндизуватися", стати нейтральною країною і вийти з ситуації у найменш травматичний спосіб9 . Схожої думки дотримується Маріано Каусіно [Mariano Caucino], пропонуючи не дражнити Росію зазіханнями на її сферу впливу: «Світова безпека та мир могли б зробити значущий крок вперед, якби західні лідери посприяли нейтральній Україні, яка б функціонувала як міст між Росією та Заходом, забувши про інтеграцію у Європейський Союз та НАТО, - для уникнення недоречних провокацій щодо свого гігантського сусіда» ${ }^{10}$.

Отож, межі дискусії щодо українського питання на сторінках La Nación - від виразно проукраїнських оцінок ситуації (більша частина аналітичних та публіцистичних текстів) до нейтральних оцінок та в дечому капітулянтських порад Україні. У виданні практично не представлений однозначно проросійський наратив.

${ }^{4}$ La Nación (2015), «Putin y el objetivo de desestabilizar a Ucrania», 12 de febrero, disponible en: t.ly/ d67ZM (consultado el 6 de noviembre de 2019).

5 Cárdenas, E. (2014), «Ucrania: la estrategia de Vladimir Putin», La Nación, 2 de septiembre, disponible en: t.ly/10AxE (consultado el 6 de noviembre de 2019).

6 Cárdenas, E. (2014), «El mundo de hoy, según Vladimir Putin», La Nación, 11 de julio, disponible en: t.ly/9DGN3 (consultado el 6 de noviembre de 2019).

7 La Nación (2015), «Putin, un líder peligroso», 20 de marzo, disponible en: t.ly/5KJLE (consultado el 6 de noviembre de 2019).

8 Bassets, L. (2014), «Crimea, la última cuenta pendiente de la guerra fría», La Nación, 23 de marzo, disponible en: $\underline{t . l y / V w 7 N y}$ (consultado el 6 de noviembre de 2019).

9 Bassets, L. (2014), «Finlandizarse», la salida menos traumática para Ucrania», La Nación, 15 de junio, disponible en: t.ly/rzVNR (consultado el 6 de noviembre de 2019).

${ }^{10}$ Caucino, M. (2015), «Occidente se equivoca con Putin», La Nación, 23 de febrero, disponible en: t.ly/0qAyx (consultado el 6 de noviembre de 2019). 
Clarín. Цього не можна сказати про іншу провідну щоденну газету Аргентини Clarín, схильну відстоювати проросійські позиції. Для ілюстрації розгляньмо детальніше матеріал у цій газеті, присвячений збитому боїнгу МН17, під назвою «Україна: розв’язані сили, які ніхто не може контролювати» (липень 2014 р.). У статті знаходимо:

1) Означення конфлікту на Сході України як «громадянська війна»;

2) Відмову покладати відповідальність на Росію за збитий боїнг, переказ версії обох сторін та зрівняння їх у такий спосіб: «Ці дві країни... звинувачують одна в одну у трагедії. Київ стверджує, що Кремль озброїв повстанців усіма видами зброї. Федерація відповідає непідтвердженими даними про невдачу українського командування при спробі влучити у літак, сприйнятий за московські військово-повітряні сили»;

3) Спроби захистити російську сторону від звинувачень Обами та поставити під сумнів підконтрольність сепаратистів Кремлю: «Сам Барак Обама, хоча і визнав, що слідство ще попереду, без вагань заявив, що допомога та поставки найголовніших ресурсів надходять повстанцям із Москви. Але він забув важливий факт: сепаратисти звинувачують Путіна у відмові їх підтримувати і в тому, що він відкрито дозволяє новому українському уряду їх знищити»;

4) Додатковий аргумент на користь того, що Росія не зацікавлена у проросійських сепаратистах Сходу України: на Донбасі Кремль не зробив жодного $з$ тих рішучих кроків, які зробив після «повстання русофілів Кримського півострова»;

5) Екстравагантне пояснення стягуванню російських військ до кордону з Україною: «...Значною мірою війська, які тримає Кремль на кордоні, видаються не стільки загрозою для України, скільки бар'єром від сепаратистів»;

6) Думку, що справжня мета Путіна - домогтися, щоб Україна надала більшої автономії проросійським регіонам поблизу кордону;

7) Думку, що повстанці - самостійна сила, яка воює проти Києва і вимагає у Москви взяти її під свою руку: «...Складається враження, що ніхто не контролює легіони повстанців, які кидають виклики і Києву, i, у формі шантажу, Росії Путіна, змушуючи його взяти на себе відповідальність» (тобто Росія ні при чому);

8) Виділяючи двох «батьків української кризи», Clarín обох знайшла в українських внутрішньополітичних процесах: це «корумпований уряд Віктора Януковича», який спровокував повстання, та сили, які привласнили революцію - «місцевий істеблішмент, підтриманий расистськими ультраправими групами, фанатично антиросійськими, які виросли на Майдані». Російський чинник в українській кризі цілковито проігноровано ${ }^{11}$.

Інший проросійський текст у Clarin, який варто розглянути детальніше - передрукований репортаж іспанського агентства $E F E$ зі Слов'янська авторства Ігнасіо Oртеги [Ignacio Ortega] (червень 2019 р.), де домінують похмурі картини спустошеного війною Донбасу та антиукраїнські коментарі місцевих жителів. Наприклад, такі: «Зі Стрєлковим жилося набагато краще. Він розстрілював злодіїв та бандитів на місці», - сперечається Васілій, молодий уродженець Слов'янська, щодо двох місяців проросійського контролю. Або такі: «Перехожі звинувачують Київ у своїх

\footnotetext{
${ }^{11}$ Clarín (2014), «Ucrania: fuerzas desatadas que nadie puede controlar», 19 de julio, disponible en: t.ly/ qYPBm (consultado el 6 de noviembre de 2019).
} 
стражданнях. Порівнюють із нацистами за жорстоке бомбардування їхніх осель». Українська влада на Донеччині показана ментально чужою: «Уряд заповнив місто плакатами українською мовою, якою майже ніхто не розмовляє. Російська - мова міжнародного спілкування для всіх. "Ми живемо під окупацією”, - кажуть багато хто з сусідів. У центрі Слов'янська з'явилася автокефальна церква, але всі йдуть до храму, пов'язаного з Московським патріархатом». Репортаж вінчає висновок про потребу мирного вирішення конфлікту, адже президентські вибори показали, що «українці не хочуть продовжувати воювати і гинути, i, незважаючи на те, що багато хто $з$ них вважає Росію державою-агресором, вони хочуть нормалізувати відносини 3 Москвою» ${ }^{12}$.

Clarín доволі наполегливо використовує властиві російській стороні характеристики української ситуації, повсякчас послуговується формулою «громадянська війна». У матеріалах за лютий 2015 р., спровокованих боями за Дебальцеве, у Clarín йдеться про «київські війська та проросійських повстанців» ${ }^{13}$, «сепаратистів та київські війська» ${ }^{14}$. У листопаді 2018 р. у статті про інцидент у Керченській протоці йдеться про «збройний конфлікт на сході між київськими військами та сепаратистами». Щодо ролі у конфлікті Росії газета не має жодної позиції: «Київ і Захід звинувачують Росію у військовій підтримці сепаратистів, що Москва заперечує» ${ }^{15}$. Навіть на п’яту річницю трагічних подій, пов'язаних зі збитим малайзійським боїнгом (липень 2019 р.), Clarín тримається версії про «збройний конфлікт на Сході України між російськими та українськими сепаратистами» ${ }^{16}$. Якщо у деяких публікаціях, наприклад 5 вересня 2014 р., і згадують про те, що «проросійські сепаратисти» користуються «підтримкою з боку Москви» і навіть про те, що конфлікт «було розв’язано починаючи з односторонньої анексії Росією українського півострова Крим та падіння в лютому українського проросійського президента Віктора Януковича», наступне речення все повертає на свої місця: «Обидві події поставили країну на поріг громадянської війни» ${ }^{17}$.

Проукраїнський наратив на шпальтах Clarín набагато скромніший. Сюди можна зарахувати розлоге інтерв’ю з Еміне Джапаровою у листопаді 2018 р., у якому перша заступниця міністра інформаційної політики України детально викладає точку зору України щодо найпринциповіших питань у конфлікті з Росією: гібридна війна, Малайзійський боїнг, отруєння Скрипалів, інцидент у Керченській протоці, історична приналежність Криму, переслідування кримських татар ${ }^{18}$. Матеріалів такого плану в Clarín украй мало порівняно з проросійськими.

${ }^{12}$ Clarín (2019), «Donbás: la guerra que ya produjo 10.000 muertos y de la que nadie habla», 3 de junio, disponible en: t.ly/Gy97d (consultado el 6 de noviembre de 2019).

${ }^{13}$ Clarín (2015), "La tregua en Ucrania se hace pedazos a tres dias de entrar en vigor», 17 de febrero, disponible en: t.ly/Ok7Ol (consultado el 6 de noviembre de 2019).

${ }^{14}$ Clarín (2015), «Aumentan los sangrientos combates en Ucrania a pocas horas de la cumbre de paz», 11 de febrero, disponible en: $\underline{\text { t.ly } / \mathrm{RkPeO}}$ (consultado el 6 de noviembre de 2019).

${ }^{15}$ Clarín (2018), «Un inesperado choque militar en el Mar Negro reaviva la tensión entre Rusia e Ucrania», 26 de noviembre, disponible en: t.ly/Gy97X (consultado el 6 de noviembre de 2019).

${ }^{16}$ Clarín (2019), «A cinco años del desastre del MH17, el diario de una tragedia», 16 de julio, disponible en: t.ly/pYVNn (consultado el 6 de noviembre de 2019).

${ }^{17}$ Clarín (2014), «Rusia, Ucrania y los separatistas prorrusos debaten un alto el fuego», 5 de septiembre, disponible en: t.ly/10ALB (consultado el 6 de noviembre de 2019).

${ }_{18}$ Clarín (2018), «No nos vamos a quedar callados ante la politica imperialista de Rusia», dice Emine Dzhaparova", 29 de noviembre. disponible en: t.ly/9DG9e (consultado el 6 de noviembre de 2019). 
Інформаційний сайт Infobae. Крізь призму цього аргентинського ресурсу події в Україні бачились у різних інтерпретаціях, зокрема у проросійській. У квітні 2014 p. Донбас мав вигляд середовища народних протестів, йшлося про «протестувальників», які «повстали проти уряду та підняли російські прапори на сході України» та про «групу активістів», яка «увірвалася в будівлю Донецької облдержадміністрації». Про Росію як чинник у регіоні не йшлося, хоча зазначалося, що «Кримський півострів анексувала Москва»19. Іншим прикладом може бути стаття під назвою «Україна і Росія, від незручних союзників до лютих ворогів» (травень 2019). Публікація містить коментарі лише одного експерта, Марсело Монтеса, які загалом відображають російське бачення ситуації: «Після 2014 року Україна розпочала політику величезних провокацій щодо російськомовних жителів Південного Сходу» (тобто відповідальність за початок конфлікту лежить на Україні). Рекомендації автора для виходу з ситуації повністю виключають Росію як фактор: «Вирішення конфлікту 3 повстанськими республіками південного сходу України проходить, серед інших аспектів, через конституційну реформу, яка приведе до федеративної системи управління та особливого статусу для Донецька і Луганська» ${ }^{20}$.

Прикладом проукраїнської інтерпретації подій в Infobae можуть бути публікації, присвячені зіткненням в Одесі 2 травня 2014 р. В одному 3 повідомлень на цю тему перемога Майдану над Януковичем названа «народним повстанням», а інцидент з Кримом потрактували як «одностороннє рішення Росії анексувати Крим після незаконного, відповідно до міжнародного права, референдуму»². Пишучи про протистояння в Одесі, сайт вважав за потрібне назвати сторону, яка почала конфлікт: «Проросійські сили напали на захисників українського уряду. Десяток людей постраждали у зіткненнях»22. Вже 4 травня йшлося про «справжню громадянську війну» та про «проросійських сепаратистів на сході країни». Наприкінці статті - коментарі представників України (прем'єр-міністра та СБУ) щодо відповідальності Росії за те, що відбувається на сході та півдні України ${ }^{23}$. Останнє слово залишилося за українською стороною, що вкрай важливо для загального сприйняття матеріалу.

Напередодні саміту G-20 у Буенос-Айресі (листопад 2018) Infobae пише, що «російські сили окупували і анексували півострів, а потім підтримали повстанців на Донбасі» ${ }^{24}$. В контексті намірів Трампа купити Гренландію (серпень 2019), Infobae бере кримський «референдум» 2014 р. у лапки, підкреслюючи таким чином його

${ }^{19}$ Infobae (2014), «Manifestantes se levantaron contra el Gobierno e izaron banderas rusas en el este de Ucrania», 6 de abril, disponible en: t.ly/kzVLJ (consultado el 6 de noviembre de 2019).

${ }^{20}$ Infobae (2019), «Ucrania y Rusia, de aliados incómodos a enemigos acérrimos», 11 de mayo, disponible en: t.ly/7nAWA (consultado el 6 de noviembre de 2019).

${ }^{21}$ Infobae (2014), "Batalla campal en el este de Ucrania: choques en Odessa dejaron al menos 38 muertos», 2 de mayo, disponible en: t.ly/3WA15 (consultado el 6 de noviembre de 2019).

${ }^{22}$ Infobae (2014), «Ucrania: Rusia solicitó reunión urgente del Consejo de Seguridad», 2 de mayo, disponible en: t.ly/vYV5m (consultado el 6 de noviembre de 2019).

${ }^{23}$ Infobae (2014), «Ucrania lanza una ofensiva para contrarrestar el avance prorruso en el este del país», 4 de mayo, disponible en: t.ly/ngVR8 (consultado el 6 de noviembre de 2019).

${ }^{24}$ Infobae (2018), «La propaganda de Ucrania contra Rusia que una empresa se negó a exhibir frente a la cumbre del G20 en Buenos Aires», 29 de noviembre, disponible en: t.ly/BqRKp (consultado el 6 de noviembre de 2019). 
фіктивність 25 . У грудні 2018 р. Даріо Мізраї [Darío Mizrahi] публікує на сайті текст про взаємини Росії та України. Відштовхуючись від поточного приводу, - інциденту у Керченській протоці, - автор не лише намагається розібратися у причинах та наслідках ситуації з українськими моряками, але й переповідає непросту історію взаємин України і Росії та переходу Криму із рук в руки. Прерогативу давати оцінки автор статті майже повністю делегував кільком експертам, при чому зберіг баланс між проукраїнським та проросійським баченням ситуації. Його власні формулювання та термінологія більшою мірою відображають українську візію: «Москва насильно анексувала Кримський півострів і посприяла повстанню на Донбасі... Росія не перестане робити все, що в її силах, щоб завадити Україні наблизитися до Європи. Окрім того, поки країна далі соціально та політично розділена, Москва матиме підстави для втручання» ${ }^{26}$.

\section{Мальвінська паралель}

У рамках кампанії виправдання анексії Криму Росія, з-поміж іншого, намагалася використовувати мальвінський прецедент: мовляв, світова спільнота не мала нічого проти референдуму рік перед тим, у 2013 р., коли жителі Мальвінських (Фолклендських) островів, які Аргентина вважає своїми, підтвердили свою приналежність до Об'єднаного Королівства. У цій позиції Кремль був синхронний із президентом Аргентини Крістіною Фернандес де Кіршнер, яка зауважила: «...Моя країна зазнає посягання на Мальвінських островах з боку Об'єднаного Королівства, і великі держави заявили про свою підтримку референдуму, який провели кельпери [мальвінці]: це подвійні стандарти. Не можна погоджуватись із принципом територіальної цілісності у Криму і не погоджуватися з ним у випадку Фолклендських островів» ${ }^{27}$. У тому ж 2014 р. Кіршнер критикувала санкції, які Захід наклав на Росію, та іншими способами солідаризувалася з Росією28.

Обидві аргентинські газети в той чи інший спосіб проінтерпретували висловлювання президента. La Nación піддала критиці проросійську складову цього аргументу, вказавши у статті Еміліо Карденаса на «подвійний стандарт» і з боку Росії, яка (на відміну від Заходу) відкинула референдум на Фолклендських островах, але допомогла організувати i, звісно, благословила схожий референдум, реалізований у Криму ${ }^{29}$. Clarín зауважила, що сама Аргентина повелася непослідовно, засудивши порушення територіальної цілісності України та проголосувавши «за» відповідну резолюцію на засіданні Ради Безпеки ООН, а кільканадцятьма днями пізніше «утрималася» під час голосування Резолюції Генасамблеї ООН про територіальну цілісність України. Тож Крістіна Кіршнер, на думку Clarín, «союзниця Путіна у числен-

${ }^{25}$ Bershidsky, L. (2019), «No es tan loca idea de comprar Groenlandia: los últimos territorios vendidos y una propuesta para las Malvinas», Infobae, 19 de agosto, disponible en: t.ly/yvPkn (consultado el 6 de noviembre de 2019).

${ }^{26}$ Mizrahi, D. (2018), «Por qué es tan difícil la relación entre Rusia y Ucrania, y hasta dónde puede llegar este nuevo pico de tensión», Infobae, 2 de diciembre, disponible en: t.ly/eNVqO (consultado el 6 de noviembre de 2019).

${ }^{27}$ Twitter (2014), «Cristina Kirchner. Como dije en Francia...», 25 de marzo, disponible en: t.ly/NK7qK (consultado el 6 de noviembre de 2019).

${ }^{28}$ Infobae (2015), «La relación con Rusia se afianza pese al enfriamiento de las economías», 25 de julio, disponible en: t.ly/9DGRe (consultado el 6 de noviembre de 2019).

${ }^{29}$ Cárdenas, E. (2014), «La Argentina, «socia estratégica» de Rusia», La Nación, 18 de julio, disponible en: t.ly/Kpz3y (consultado el 6 de noviembre de 2019). 
них міжнародних та двосторонніх справах», раніше «приєдналася до Вашингтона» в осуді відокремлення Криму, а тепер «вирішила утриматися, опосередковано підтримавши Путіна» ${ }^{30}$.

В іншому матеріалі Clarín зауважувала, що право прив’язувати кримську ситуацію до мальвінської дають деякі паралелі, зокрема те, що хоча більшість латиноамериканців підтримують позицію Аргентини, жителі островів на референдумі 2013 р. проголосували за те, щоб залишатися британською заморською територією (99,8\%). Незважаючи на озвучені позиції, Clarín не поскупилася на докір і на адресу російської сторони, - «у 1982 р. Москва не заветувала резолюцію ООН 502, яка закликала вивести аргентинські війська [3 Мальвінських островів]»»

Напередодні кримського «референдуму» у березні 2014 р. Infobae виніс у заголовок однієї з новин цитату міністра закордонних справ РФ Сєргєя Лаврова: “Крим означає більше для Росії, ніж Фолклендські острови для Великобританії”. Хоча у тексті новини ситуацію прокоментовано без помітних проросійських симпатій: «Автономна Республіка Крим, населена здебільшого російськомовними та етнічними росіянами, призначила на 16 березня референдум про приєднання до Росії, тоді як російські війська без розпізнавальних знаків продовжують брати під контроль стратегічні об'єкти на півострові» ${ }^{32}$. До дня ветеранів і жертв Мальвінської війни, який в Аргентині відзначають 2 квітня 2014 р., Infobae опублікував інтерв'ю із впливовим аргентинським бізнесменом Маріо Монтото [Mario Montoto]. Останній погодився 3 аргументом президента, звинувативши у непослідовності британський уряд 33 .

Наслідки української проблеми

В усіх трьох виданнях є автори, які не демонструють наміру розбиратися, на чиєму боці рація, піклуючись насамперед глобальними наслідками конфлікту. Рохеліо Пфіртер [Rogelio Pfirter] у La Nación робить акцент на небаченому з часів Холодної війни напруженні між Заходом та Росією, - «криза в Україні породжує обгрунтовану додаткову тривогу у міжнародної спільноти» ${ }^{34}$.

Infobae у переддень т. зв. «референдуму» у Криму у березні 2014 р.: «Влада та громадяни знають, що голосування «за» призведе до великої міжнародної кризи» ${ }^{35}$. У матеріалі за 4 травня 2014 р., після подій в Одесі, Infobae подає і позицію України («Росія послала сюди людей, щоб створити хаос»), і позицію Росії (український уряд здійснює «каральну акцію проти власного народу», а Захід мовчить), залишаючи читачеві право обирати, хто більше заслуговує на довіру. Натомість найбільший акцент зроблено на можливих негативних наслідках конфлікту для аграрної сфери:

${ }^{30}$ Clarín (2014), «La ONU condenó a Rusia por Crimea, pero Argentina decidió abstenerse», 28 de marzo, disponible en: t.ly/7nAeA (consultado el 6 de noviembre de 2019).

${ }^{31}$ Clarín (2014), «Crimea, Malvinas y la Guerra fría», 21 de marzo, disponible en: t.ly/MkBqV (consultado el 6 de noviembre de 2019).

${ }^{32}$ Infobae (2014), «Crimea significa más para Rusia que las Islas Malvinas para Gran Bretaña», 14 de marzo, disponible en: t.ly/EdWlK (consultado el 6 de noviembre de 2019).

${ }^{33}$ Infobae (2014), «Debemos rescatar el ejemplo de los héroes anónimos de Malvinas», 5 de abril, disponible en: t.ly/JO5rY (consultado el 6 de noviembre de 2019).

${ }^{34}$ Pfirter, R. (2014), «Daño colateral de la crisis en Ucrania», La Nación, 15 de septiembre, disponible en: t.ly/gYvX6 (consultado el 6 de noviembre de 2019).

${ }^{35}$ Infobae (2014), «¿Por qué Crimea quiere convertirse en territorio de Rusia?», 16 de marzo, disponible en: t.ly/w91Nx (consultado el 6 de noviembre de 2019). 
«Названа «житницею Європи» за свої чорні землі, одні з найбільш родючих у світі, Україна зараз викликає тривогу через сільськогосподарські ринки у всьому світі ${ }^{36}$.

Запрошений колумніст Clarín Феліпе де ла Бальсе [Felipe de la Balze] у червні 2016 р. починає з тривоги за долю планети, - «вперше після закінчення Холодної Війни глибока геополітична тріщина загрожує стабільності і миру на європейському континенті». Першопричину цієї тріщини автор вбачає у намаганні Євросоюзу та НАТО поширити свій економічний, політичний та військовий вплив не лише на країни Центральної та Східної Європи, але й на традиційних сателітів Росії, колишні республіки СРСР. За версією автора, саме експансія Заходу спровокувала відповідну реакцію Росії (а не навпаки): «Державний переворот у Києві (Україна) у лютому 2014 року проти авторитарного та проросійського президента - але демократично обраного - був тією краплею, яка переповнила чашу». Де ла Бальсе визнає за Росією агресивні дії, - «російська військова окупація Кримського півострова та проросійське сепаратистське повстання (приховано підтримане Москвою) у східному регіоні України (Донбас)», - проте на тлі наведеної вище передісторії вони повинні видаватися читачеві доволі вмотивованими. Де ла Бальсе доходить висновку, що для того, щоб запобігти «подальшому віддаленню між західними союзниками та Росією», «стратегічному та військовому союзу між Росією та Китаєм», «серйозним наслідкам для глобального геополітичного балансу» та ускладненням «для таких країн, як Аргентина, чиї довгострокові національні інтереси передбачають економіку відкритого світу», Росії та США слід піти на взаємні поступки. Автор не заперечує, що Сполучені Штати та їхні європейські союзники повинні підтвердити своє непохитне зобов'язання захищати країни-члени НАТО від нападу Росії, зокрема Польщу та країни Балтії. «Але водночас, - пише де ла Бальсе, - вони повинні взяти на себе зобов'язання не поширювати НАТО на російську «ближню периферію», визнати анексію Криму i, в обмін на вихід російських військ з української території, переконати київський уряд у тому, щоб той надав широкі можливості для автономії своїм східним провінціям». Усе це - з перспективою подальшого включення Росії у розширений європейський простір та НАТО, що забезпечить мир у Європі та лібералізацію Росії ${ }^{37}$.

Перспективи подальших досліджень пов'язуємо із необхідністю подальшого вивчення образу України у світових медіа (зокрема латиноамериканських) та чинників, які його формують.

\section{Висновки}

1) Трактування подій в Україні у аргентинських медіа доволі складне і багатопланове, зумовлене неоднозначною позицією самої Аргентини, наявністю сильних проамериканського та проросійського лобі, які почергово перехоплюють ініціативу одне в одного. Дослідження трьох найпопулярніших видань Аргентини стосовно висвітлення подій в Україні впродовж останніх п’яти років дає підстави говорити про приблизну рівновагу між проукраїнськими та проросійськими оцінками. La Nación виявляє проукраїнське бачення ситуації набагато частіше за проросійське. Clarín навпаки, містить набагато більше проросійських матеріалів. Контент Infobae не демон-

\footnotetext{
${ }^{36}$ Infobae (2014), «Ucrania: activistas prorrusos ahora se lanzan sobre Odessa», 4 de mayo, disponible en: t.ly/Gy9KX (consultado el 6 de noviembre de 2019).

${ }^{37}$ Balze de la, F. (2016), «Rusia diseña un mapamundi riesgoso», Clarín, 26 de junio, disponible en: t.ly/ Ok7mA (consultado el 6 de noviembre de 2019).
} 
струє послідовної прихильності до жодної з версій подій в Україні. Діапазон оцінок в усіх трьох медіа доволі широкий, від явно проукраїнської до явно проросійської. Термінологія, якою послуговуються аргентинські видання, є непослідовною комбінацією української та російської термінологій.

2) Спроби президента Аргентини та проросійських сил в Аргентині нав’язати паралель між «референдумом» у Криму та референдумом на Мальвінських (Фолклендських) островах у 2013 р. не увінчалася успіхом, більшість оглядачів не підтримала президента, хоча були і аргументи на користь такого порівняння.

3) Поряд із проукраїнськими та проросійськими інтерпретаціями подій на південному сході України, доволі поширеним є занепокоєння через наслідки цих подій для світу та Аргентини - без чітких намірів розібратися у їхніх причинах. Із виявів цієї тривоги у провідних аргентинських медіа за тих чи інших обставин можна зробити і висновки, корисні Україні, і такі, які будуть на руку Росії. Однак здебільшого мислення у цьому ключі виводить авторів на інтерпретацію, описану у статті Феліпе де ла Бальсе: Росія - потуга, яка має право на свою сферу впливу, тому їі краще не провокувати.

Просування російської позиції в Аргентині забезпечують російські медіа, проросійські автори у неросійських медіа, агенти впливу під виглядом незалежних експертів. Україна не має співмірного інформаційного ресурсу і збалансовує російський інформаційний вплив винятково за рахунок підтримки західних медіа. Це тривожна для України обставина, яка дається взнаки все більше.

\section{REFERENCES}

1. All you can read (2019), «Top 30 Argentina Newspapers \& News Media», available at: t.ly/jRVZv (accessed 6 November 2019).

2. Balze de la, F. (2016), "Rusia diseña un mapamundi riesgoso", Clarín, 26 de junio, disponible en: t.ly/Ok7mA (consultado el 6 de noviembre de 2019).

3. Bassets, L. (2014), «Finlandizarse», la salida menos traumática para Ucrania, La Nación, 15 de junio, disponible en: t.ly/rzVNR (consultado el 6 de noviembre de 2019).

4. Bassets, L. (2014), «Crimea, la última cuenta pendiente de la guerra fría», La Nación, 23 de marzo, disponible en: t.ly/Vw7Ny (consultado el 6 de noviembre de 2019).

5. Bershidsky, L. (2019), «No es tan loca idea de comprar Groenlandia: los últimos territorios vendidos y una propuesta para las Malvinas», Infobae, 19 de agosto, disponible en: t.ly/yvPkn (consultado el 6 de noviembre de 2019).

6. Bosoer, F., Filchenstein, F. (2014), «Russia Today, Argentina Tomorrow», New York Times, October 21, available at: t.ly/mgV9A (accessed 6 November 2019).

7. Cárdenas, E. (2014), «El mundo de hoy, según Vladimir Putin», La Nación, 11 de julio, disponible en: t.ly/9DGN3 (consultado el 6 de noviembre de 2019).

8. Cárdenas, E. (2014), «La Argentina, «socia estratégica» de Rusia", La Nación, 18 de julio, disponible en: t.ly/Kpz3y (consultado el 6 de noviembre de 2019).

9. Cárdenas, E. (2014), «Ucrania: la estrategia de Vladimir Putin», La Nación, 2 de septiembre, disponible en: t.ly/10AxE (consultado el 6 de noviembre de 2019).

10. Caucino, M. (2015), «Occidente se equivoca con Putin», La Nación, 23 de febrero, disponible en: t.ly/0qAyx (consultado el 6 de noviembre de 2019). 
11. Clarín (2014), «Crimea, Malvinas y la Guerra fría», 21 de marzo, disponible en: t.ly/ MkBqV (consultado el 6 de noviembre de 2019).

12. Clarín (2014), «La ONU condenó a Rusia por Crimea, pero Argentina decidió abstenerse», 28 de marzo, disponible en: t.ly/7nAeA (consultado el 6 de noviembre de 2019).

13. Clarín (2014), «Rusia, Ucrania y los separatistas prorrusos debaten un alto el fuego», 5 de septiembre, disponible en: t.ly/10ALB (consultado el 6 de noviembre de 2019).

14. Clarín (2014), «Ucrania: fuerzas desatadas que nadie puede controlar», 19 de julio, disponible en: t.ly/qYPBm (consultado el 6 de noviembre de 2019).

15. Clarín (2015), «Aumentan los sangrientos combates en Ucrania a pocas horas de la cumbre de paz», 11 de febrero, disponible en: t.ly/ $\mathrm{RkPeO}$ (consultado el 6 de noviembre de 2019).

16. Clarín (2015), «La tregua en Ucrania se hace pedazos a tres días de entrar en vigor», 17 de febrero, disponible en: t.ly/Ok7Ol (consultado el 6 de noviembre de 2019).

17. Clarín (2018), "«No nos vamos a quedar callados ante la politica imperialista de Rusia», dice Emine Dzhaparova", 29 de noviembre. disponible en: t.ly/9DG9e (consultado el 6 de noviembre de 2019).

18. Clarín (2018), «Un inesperado choque militar en el Mar Negro reaviva la tensión entre Rusia e Ucrania», 26 de noviembre, disponible en: t.ly/Gy97X (consultado el 6 de noviembre de 2019).

19. Clarín (2019), «A cinco años del desastre del MH17, el diario de una tragedia», 16 de julio, disponible en: t.ly/pYVNn (consultado el 6 de noviembre de 2019).

20. Clarín (2019), «Donbás: la guerra que ya produjo 10.000 muertos y de la que nadie habl»", 3 de junio, disponible en: t.ly/Gy97d (consultado el 6 de noviembre de 2019).

21. Infobae (2014), «Crimea significa más para Rusia que las Islas Malvinas para Gran Bretaña», 14 de marzo, disponible en: t.ly/EdWIK (consultado el 6 de noviembre de 2019).

22. Infobae (2014), «Debemos rescatar el ejemplo de los héroes anónimos de Malvinas», 5 de abril, disponible en: t.ly/JO5rY (consultado el 6 de noviembre de 2019).

23. Infobae (2014), «Por qué Crimea quiere convertirse en territorio de Rusia?», 16 de marzo, disponible en: t.ly/w91Nx (consultado el 6 de noviembre de 2019).

24. Infobae (2014), «Batalla campal en el este de Ucrania: choques en Odessa dejaron al menos 38 muertos», 2 de mayo, disponible en: t.ly/3WA15 (consultado el 6 de noviembre de 2019).

25. Infobae (2014), «Manifestantes se levantaron contra el Gobierno e izaron banderas rusas en el este de Ucrania», 6 de abril, disponible en: t.ly/kzVLJ (consultado el 6 de noviembre de 2019).

26. Infobae (2014), «Ucrania lanza una ofensiva para contrarrestar el avance prorruso en el este del pais», 4 de mayo, disponible en: t.ly/ngVR8 (consultado el 6 de noviembre de 2019).

27. Infobae (2014), «Ucrania: activistas prorrusos ahora se lanzan sobre Odessa», 4 de mayo, disponible en: t.ly/Gy9KX (consultado el 6 de noviembre de 2019).

28. Infobae (2014), «Ucrania: Rusia solicitó reunión urgente del Consejo de Seguridad», 2 de mayo, disponible en: t.ly/vYV5m (consultado el 6 de noviembre de 2019).

29. Infobae (2015), «La relación con Rusia se afianza pese al enfriamiento de las economías», 25 de julio, disponible en: t.ly/9DGRe (consultado el 6 de noviembre de 2019). 
30. Infobae (2018), «La propaganda de Ucrania contra Rusia que una empresa se negó a exhibir frente a la cumbre del G20 en Buenos Aires», 29 de noviembre, disponible en: t.ly/BqRKp (consultado el 6 de noviembre de 2019).

31. Infobae (2019), «Ucrania y Rusia, de aliados incómodos a enemigos acérrimos», 11 de mayo, disponible en: t.ly/7nAWA (consultado el 6 de noviembre de 2019).

32. La Nación (2015), «Putin y el objetivo de desestabilizar a Ucrania», 12 de febrero, disponible en: t.ly/d67ZM (consultado el 6 de noviembre de 2019).

33. La Nación (2015), «Putin, un líder peligroso», La Nación, 20 de marzo, disponible en: t.ly/5KJLE (consultado el 6 de noviembre de 2019).

34. Mizrahi, D. (2018), «Por qué es tan difícil la relación entre Rusia y Ucrania, y hasta dónde puede llegar este nuevo pico de tensión», Infobae, 2 de diciembre, disponible en: t.ly/eNVqO (consultado el 6 de noviembre de 2019).

35. Pfirter, R. (2014), «Daño colateral de la crisis en Ucrania», La Nación, 15 de septiembre, disponible en: t.ly/gYvX6 (consultado el 6 de noviembre de 2019).

36. SimilarWeb (2019), «Top sites ranking for News And Media in Argentina», disponible en: t.ly/ngVZY (accessed 6 November 2019).

37. Twitter (2014), "Cristina Kirchner. Como dije en Francia...», 25 de marzo, disponible en: t.ly/NK7qK (consultado el 6 de noviembre de 2019). 


\title{
THE UKRAINIAN QUESTION IN THE MIRROR OF ARGENTINIAN PRESS (CLARÍN, LA NACIÓN AND INFOBAE)
}

\author{
Iurii Melnyk \\ Ivan Franko National University of Lviv, \\ Generala Chuprynky Str. 49, 79044, Lviv, Ukraine \\ e-mail:melnykiurii@gmail.com \\ https://orcid.org/0000-0002-2825-9925
}

The main objective of the study is to outline the confrontation between the proUkrainian and pro-Russian vision of events in Ukraine in 2014-2019 in three main Argentina's newspapers. The journalistic texts for the research have been found on the official websites of the corresponding newspapers using the keyword "Ucrania" ("Ukraine"). The texts with irrelevant mentions of Ukraine were eliminated, all the rest were analyzed using induction, comparison, classification analysis, content analysis, vocabulary analysis.

The interpretation of the Ukrainian events in the Argentinean media is quite complex and multifaceted, due to the ambiguous position of Argentina itself, the presence of strong proAmerican and pro-Russian lobbies, which alternately seized the initiative. The study reveals an approximate balance between pro-Ukrainian and pro-Russian assessments. La Nación proposes a pro-Ukrainian vision of the situation much more often than pro-Russian. Clarin, on the contrary, contains significantly more pro-Russian materials. Infobae's content does not demonstrate a consistent commitment to one of the versions of the events in Ukraine. The range of estimations in all three media is quite wide, from clearly pro-Ukrainian to clearly proRussian. The terminology used by all three leading Argentinian newspapers is an inconsistent combination of Ukrainian and Russian terminologies.

Along with pro-Ukrainian and pro-Russian interpretations of the events in Ukraine, quite common is a concern about the consequences of these events for the world and Argentina, without clear intention to sort out their causes. In most cases, thinking in this directions leads the authors to the interpretation described in an article by Felipe de la Balze: Russia is a force that has the right to its sphere of influence, therefore it is better not to provoke it.

Key words: Argentinian media, Clarín, La Nación, Infobae, image of Ukraine, Ukrainian issue. 